\title{
New insights into the methodological issues of the indicator amino acid oxidation method in preterm neonates
}

\author{
Femke de Groof', Lisha Huang', Jos W.R. Twisk², Gardi J.Voortman', Waheeda Joemai', Carmen H. Hau', Henk Schierbeek', \\ Chao Chen ${ }^{4}$, Ying Huang ${ }^{5}$ and Johannes B. van Goudoever ${ }^{3,6}$
}

BACKGROUND: We determined the effect of adaptation to the study diet on oxidation of the indicator amino acid and the required tracer washout time in preterms.

METHODS: Subjects received a study diet for $6 \mathrm{~d}$ that entailed a 50\% reduction in leucine. Tracer studies using enterally infused $\left[{ }^{13} \mathrm{C}\right]$ bicarbonate and $\left[1-{ }^{13} \mathrm{C}\right]$ phenylalanine were performed on days $1,2,4$, and 6 . Breath samples containing ${ }^{13} \mathrm{CO}_{2}$ were collected during steady state and measured by infrared spectrometric analysis, and the fraction of ${ }^{13} \mathrm{CO}_{2}$ recovery from ${ }^{13} \mathrm{C}$ oxidation $\left(\mathrm{F}^{13} \mathrm{CO}_{2}\right)$ was calculated.

RESULTS: Preterm infants ( $n=11$, birth weight $1.9 \pm 0.1 \mathrm{~kg}$, gestational age $32.6 \pm 1.5 \mathrm{wk}$ ) received $166 \mathrm{mg} / \mathrm{kg} / \mathrm{d}$ of leucine. Baseline enrichment changed significantly at day 1 of the study diet. $\mathrm{F}^{13} \mathrm{CO}_{2}$ did not change significantly between days 2 and 4 but was significantly lower at day 6 . The tracer washout time was determined to be $7.5 \mathrm{~h}$ using a biphasic regression analysis.

CONCLUSION: One day of adaptation to a new diet is necessary to adapt to the ${ }^{13} \mathrm{C}$ enrichment of the study formula before starting infant requirement studies. Adaptation for a period of $5 \mathrm{~d}$ results in a protein-sparing response. The minimal time between two studies within the same subject is $7.5 \mathrm{~h}$.

A dequate nutrition is essential for optimal growth and development in preterm and term neonates. Protein is an important component because it provides essential amino acids required for protein synthesis and growth. Nitrogen balance has long been used as the method to determine the requirement of the essential amino acids. An adaptation time of $7 \mathrm{~d}$ was required to achieve equilibrium in the urea body pool and in urinary urea excretion (1). Because it is considered unethical to administer a deficient diet to an infant for 7-10 d, alternative methods were needed. The oxidation (or hydroxylation) of essential amino acids by the liver and peripheral tissues is dependent on the activity of the degrading enzymes, which in turn are dependent on the intake of the essential amino acids. Consequently, it is necessary to have sufficient time to adapt to a changing dietary intake $(2,3)$.
Studies have been performed using tracer oxidation methods in adults and pigs to examine whether protein intake or the time to adapt to the study diet influenced the amino acid kinetics. Following a $2 \mathrm{~d}$ strictly controlled normal protein intake, an adaptation time of $8 \mathrm{~h}$ appears to be sufficient for adult subjects $(4,5)$. In premature or term infants, no studies have been performed to determine the necessary adaptation time. Amino acid and protein turnover in infants are two to three times higher than in adults on average, potentially reflecting a more highly adaptive system to changes in the diet $(6,7)$. The adaptation to the study diet should be as short as possible to avoid restrictions in growth and development in this vulnerable population. This is especially true when considering preterm infants because protein intake in the first $4 \mathrm{wk}$ of life has a major influence on later cognitive function $(8,9)$ and blood pressure $(10)$.

Therefore, we performed a study to determine the period of adaptation in infants who receive a study diet with decreased leucine content. We measured the oxidation rate of the indicator amino acid $\left[1-{ }^{13} \mathrm{C}\right]$ phenylalanine to $\mathrm{F}^{13} \mathrm{CO}_{2}$. In addition, we determined the minimal time needed to perform the next tracer study by determining the tracer washout time after $2 \mathrm{~d}$ adaptation to the study diet.

\section{RESULTS}

Eleven patients were enrolled in the study, and the patient characteristics are shown in Table 1. Weight gain rates tended to decrease during the study as compared with rates before the study, but this trend did not reach significance. In addition, the study was not designed or powered to detect differences in weight gain rates. No correlation was observed between growth during the study and the fraction of ${ }^{13} \mathrm{CO}_{2}$ recovery from $\left[1-{ }^{13} \mathrm{C}\right]$ phenylalanine oxidation $\left(\mathrm{F}^{13} \mathrm{CO}_{2}\right)$.

\section{Tracer Washout Time}

The tracer washout time studies were performed on day 2 . In one patient two tracer washout studies were performed at day 2 and day 4; therefore, a total of 12 tracer washout studies were performed. After the end of the study protocol, the ${ }^{13} \mathrm{C}$

\footnotetext{
'Division of Neonatology, Department of Pediatrics, Erasmus Medical Center, Sophia Children's Hospital Rotterdam, Rotterdam, The Netherlands; ${ }^{2}$ Department of Methodology and Applied Biostatistics, Vrije Universiteit (VU) Medical Center, Amsterdam, The Netherlands; ${ }^{3}$ Department of Pediatrics, Emma's Children's Hospital, Academic Medical Center, Amsterdam, The Netherlands; ${ }^{4}$ Department of Pediatrics, Division of Neonatology, Fudan Children's Hospital of Fudan University, Shanghai, People's Republic of China; ${ }^{5}$ Department of Pediatrics, Division of Gastro-Enterology, Fudan Children's Hospital of Fudan University, Shanghai, People's Republic of China; ${ }^{6}$ Department of Pediatrics, Vrije Universiteit (VU) Medical Center, Amsterdam, The Netherlands. Correspondence: Johannes B. van Goudoever (h.vangoudoever@amc.nl)
} 
Table 1. Characteristics of subjects $(N=11)$

\begin{tabular}{lc}
\hline & Mean \pm SD \\
\hline Birth weight $(\mathrm{g})$ & $1,860 \pm 143$ \\
Gestational age $(\mathrm{wk})$ & $32.6 \pm 1.5$ \\
Postnatal age (d) & $17.4 \pm 8.2$ \\
Postconceptional age (wk) & $35.0 \pm 1.1$ \\
Study weight (g) & $1,948 \pm 150$ \\
Growth before study (g/kg/d) & $15.0 \pm 3.8$ \\
Growth during the $6 \mathrm{~d}$ study diet $(\mathrm{g} / \mathrm{kg} / \mathrm{d})$ & $12.5 \pm 5.5$ \\
kcal before study (kcal/kg/d) & $109.6 \pm 15.4$ \\
kcal during study (kcal/kg/d) & $134.4 \pm 2.9^{*}$ \\
Protein intake $1 \mathrm{~d}$ before study $(\mathrm{g} / \mathrm{kg} / \mathrm{d})$ & $3.03 \pm 0.36$ \\
Protein intake during study $(\mathrm{g} / \mathrm{kg} / \mathrm{d})$ & $3.67 \pm 0.08^{*}$ \\
\hline
\end{tabular}

${ }^{*} P<0.05$ between before study and during study using paired $t$-test (two-tailed).

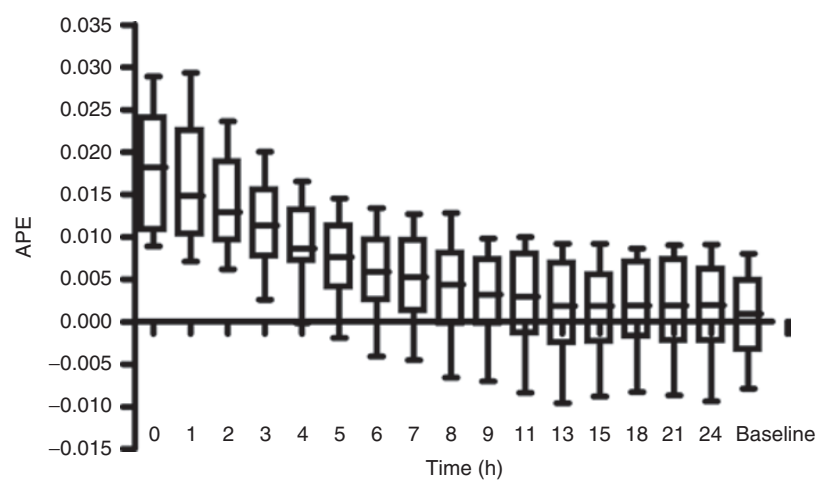

Figure 1. Tracer washout time. From the two-phase regression analysis with time as the independent variable and ${ }^{13} \mathrm{C}$ enrichment in atom percent excess (APE) as the dependent variable, the break point was determined to be $7.5 \mathrm{~h}$ (upper confidence interval $(\mathrm{Cl}): 8.1 \mathrm{~h}$; lower $\mathrm{Cl}: 6.8 \mathrm{~h}$ ). The return to baseline enrichments was determined to be $7.5 \mathrm{~h}(N=11)$.

enrichment decreased, and stable background enrichment was determined using a biphasic regression analysis. From the twophase regression analysis with time as the independent variable and ${ }^{13} \mathrm{C}$ enrichment in atom percent excess (APE) as the dependent variable, the break point was determined to be $7.5 \mathrm{~h}$ $\left(r^{2}=0.43, P<0.000\right)$ (upper confidence interval: $8.1 \mathrm{~h}$; lower confidence interval: $6.8 \mathrm{~h}$ ). The return to baseline enrichments was determined to be $7.5 \mathrm{~h}$. These results are depicted in Figure 1.

\section{Baseline Enrichments}

Baseline enrichments were significantly decreased on the first day as compared with all other study days (Table 2). The enrichment increased by the second day on the study formula. A small, statistically significant difference of $1 \delta$ Pee Dee Belemnite (PDB) was observed between the baseline enrichments measured on day 2 and 4 , and day 2 and day 6 by using a paired $t$-test. These differences were considered not relevant because they are within $1 \delta \mathrm{PDB}$ difference, which is within the precision range of this technique. The baseline at day 6 is lower than day 4 , whereas the baseline at day 2 is higher than day 4 (Figure 2). Therefore, we
Table 2. Comparison between days $1,2,4$, and 6 using paired $t$-tests $($ mean \pm SD)

\begin{tabular}{|c|c|c|c|c|}
\hline & Day 1 & Day 2 & Day 4 & Day 6 \\
\hline Baseline PDB & $-23.4 \pm 1.1$ & $-17.2 \pm 1.3^{*}$ & $-16.1 \pm 1.2^{*, * *}$ & $-16.3 \pm 1.1^{*,+}$ \\
\hline $\begin{array}{l}\text { Fractional } \\
\text { oxidation (\%) }\end{array}$ & & $14.6 \pm 6.6$ & $13.0 \pm 5.9$ & $11.1 \pm 5.6^{\dagger, t}$ \\
\hline $\begin{array}{l}\text { Body } \mathrm{CO}_{2} \\
\text { production } \\
(\mathrm{mmol} / \mathrm{kg} / \mathrm{h})\end{array}$ & & $26.7 \pm 1.8$ & $28.0 \pm 2.4$ & $28.9 \pm 1.8$ \\
\hline \multicolumn{5}{|c|}{ PDB, Pee Dee Belemnite. } \\
\hline $\begin{array}{l}{ }^{*} P<0.05 \text { betwe } \\
\text { (two-tailed). }{ }^{\dagger} P \\
\text { day } 6 \text { (two-tailed }\end{array}$ & $\begin{array}{l}1 \text { and day } 2 \\
\text { etween day }\end{array}$ & $\begin{array}{l}\text { two-tailed) } \\
\text { d day } 6 \text { (tw }\end{array}$ & $\begin{array}{l}0.05 \text { between } \\
\text { d). }{ }^{\ddagger} P<0.05 \text { be }\end{array}$ & $\begin{array}{l}\text { lay } 2 \text { and day } 4 \\
\text { ween day } 4 \text { and }\end{array}$ \\
\hline
\end{tabular}

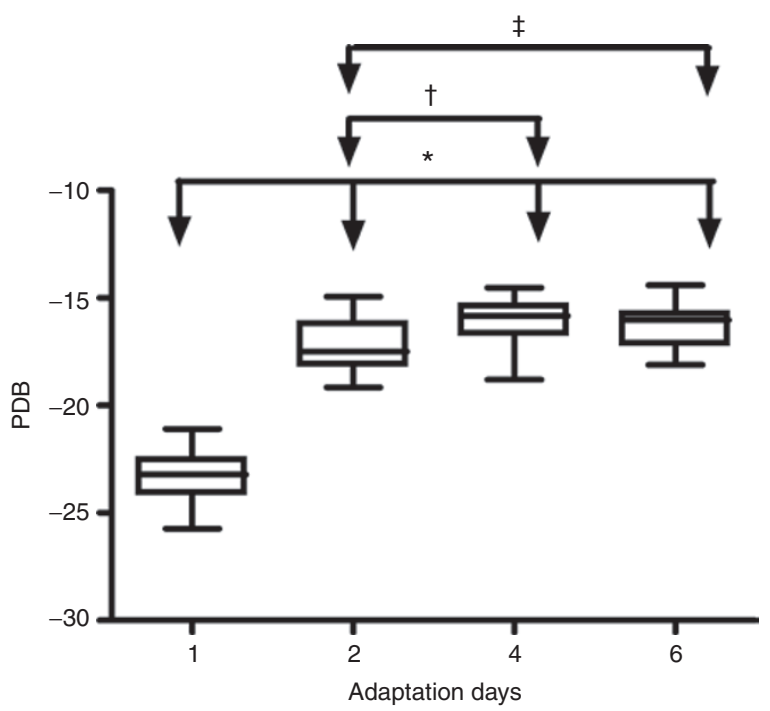

Figure 2. Mean $\pm S D{ }^{13} \mathrm{C}$ baseline enrichment of day 1 vs. day 2 , 4, and 6 in PeeDee Belemnite (PDB). ${ }^{*} P<0.05$ between day 1 and day 2/4/6 (twotailed); ${ }^{\dagger} P<0.05$ between day 2 and day 4 (two-tailed); ${ }^{\ddagger} P<0.05$ between day 2 and day 6 (two-tailed). The difference between day 2 and 4 and day 2 and 6 , although significant, is within the measurement error of the mass spectrometry measurements and therefore a physiologically irrelevant difference.

state that the $1 \delta$ PDB difference between day 2 and 4 , although significant, is a really small difference and does not influence the oxidation data. The large change in the baseline enrichment on the first day on the study formula made it impossible to calculate the whole-body $\mathrm{CO}_{2}$ for that day. The body $\mathrm{CO}_{2}$ production estimated by the infusion of $\left[{ }^{13} \mathrm{C}\right]$ bicarbonate did not differ between days 2,4 , and 6 , indicating that energy expenditure did not change over the study period. Figure 3 shows the isotopic plateaus during $\left[{ }^{13} \mathrm{C}\right]$ bicarbonate and $\left[1-{ }^{13} \mathrm{C}\right]$ phenylalanine infusion of day 2 as an example of the steady states achieved during the study protocol.

\section{Oxidation Rate of the Indicator}

No difference was observed in $\mathrm{F}^{13} \mathrm{CO}_{2}$ levels in infants receiving the study formula between days 2 and 4 . However, day 6 $\mathrm{F}^{13} \mathrm{CO}_{2}$ was significantly lower than that measured on the preceding days (days 2 and $6, P=0.033$; days 4 and $6, P=0.043$ ) (Table 2). 


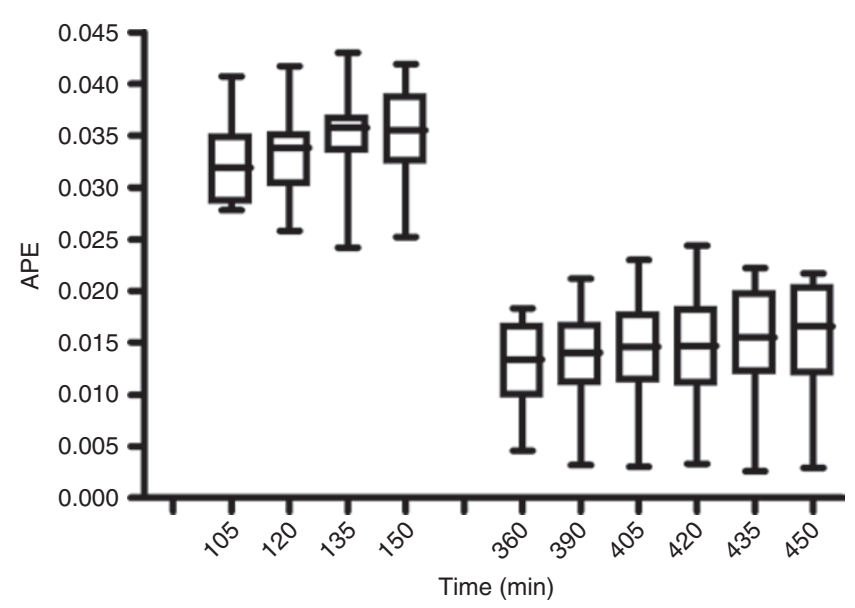

Figure 3. Mean $\pm S D{ }^{13} \mathrm{C}$ enrichment in atom percent excess (APE) in expired air during $\left[{ }^{13} \mathrm{C}\right]$ bicarbonate infusion (T105-T150) and during $\left[1-{ }^{13} \mathrm{C}\right]$ phenylalanine infusion $(\mathrm{T} 360-\mathrm{T} 450)$ at day $2(N=11) . \mathrm{T}$, time.

\section{DISCUSSION}

Several interesting issues emerge from the present studies. First, energy expenditure is remarkably stable over a period of slightly less than a week. Second, the washout time of tracer is not a rate-limiting step in performing subsequent studies in infants because APE is not significantly different from zero from $8 \mathrm{~h}$ onward.

However, the present data do not allow us to draw firm conclusions about the time to adapt to a study diet. On the one hand, we did not observe differences in fractional oxidation rates between days 2 and 4 . On the other hand, we did observe a significantly lower oxidation rate after $5 \mathrm{~d}$ of adaptation. This coincided with a lower weight gain rate observed after a period of $6 \mathrm{~d}$. These results can be interpreted in two ways. First, a period of at least $5 \mathrm{~d}$ of adaptation to a study diet is necessary in indirect amino acid oxidation (IAAO) studies determining the amino acid requirements in preterm infants. Second, the body adapts to a reduced essential amino acid intake by decreasing the growth rate, which again is reflected by a new equilibrium. In the new equilibrium, there is a decreased requirement for essential amino acids because growth is reduced. Therefore, a requirement determined under those circumstances would not reflect the optimal intake. If this theory were true, this would reflect the remarkable flexibility of the human body to adapt to changing circumstances. However, one would expect a higher oxidation rate of the indicator amino acid, whereas we observed the opposite. For example, Moehn et al. observed higher oxidation rates of the indicator in pigs fed a low-protein diet after a 1-2 d adaptation to the study diet using phenylalanine flux and enriched expired $\mathrm{CO}_{2}$ (11). One possible explanation for our results is that the plasma phenylalanine concentration (the indicator amino acid) increased, resulting in a lower intestinal absorption of the dietary phenylalanine, including the enterally administered ${ }^{13} \mathrm{C}$ phenylalanine. Subsequently, plasma enrichment would have been lower, resulting in a lower ${ }^{13} \mathrm{CO}_{2}$ production rate. Unfortunately, we did not collect blood or urine samples to enable us to test this hypothesis. The second explanation could be that in the study diet the ${ }^{13} \mathrm{C}$ content of protein/amino acids was much lower than that of the carbohydrate component. Subsequently, a switch from carbohydrate oxidation to amino acid oxidation may cause a switch in ${ }^{13} \mathrm{CO}_{2}$ production. A higher protein oxidation would lead to lower ${ }^{13} \mathrm{C}$ in breath, which could compensate for the higher tracer oxidation.

Adaptation to a specific diet has been widely studied. Enzymes involved in the metabolism of dispensable amino acids responded to the amount of protein consumed, whereas enzymes involved in the catabolism of indispensable amino acids adapted to changes in protein intake (and indispensable amino acid intake) in relation to the amino acid needs of the body. Thus, the capacity to degrade amino acids depends to a considerable extent on the diet. A change in the intake of an amino acid is promptly (within a few hours) followed by a parallel change in its oxidation rate $(12,13)$. This would imply that when the adaptation to the enrichment of the diet is achieved, an oxidation study can be performed within $8 \mathrm{~h}$, as shown by Elango et al. (5). It was shown that long-term adaptation to a specific amino acid-deficient diet does not result in changes of other amino acids in adults (14) but can decrease oxidation of the test amino acid, indicating a decrease in catabolism to maintain the body's equilibrium $(15,16)$. Because these studies used the direct amino acid oxidation method, which is proposed to produce low oxidation rates in response to lower intakes of the test amino acid, these results are not comparable with our results using the IAAO method, in which deficient intakes are proposed to give high oxidation rates. Therefore, these direct oxidation studies involved a change in the pool size of the amino acid being oxidized due to the change in the dietary intake of the same amino acid. By contrast, because the IAAO technique employs an unchanging intake and pool size for the oxidized amino acid, it should be expected that the adaptation period for the IAAO method would be at least as short as that for the direct oxidation method and possibly shorter (11). This would imply that in infants, if adaptation to the enrichment of the study diet has been achieved, an oxidation study could be performed within hours as in adults. A recent IAAO study demonstrated no differences in lysine requirements in adults adapted to lower protein intakes, with the remark that the test formulas were given only on the study day (17). To clear this controversy, a study should be performed that compares the requirement of an essential amino acid after 1,5, or more days of adaptation and meanwhile should take the reduced growth into account. Because we consider it unethical to maintain neonates for long periods on a deficient diet, we did not test adaptation longer than $6 \mathrm{~d}$ and consequently did not resolve the question of whether more than $6 \mathrm{~d}$ has an additional effect on the tracer oxidation. Furthermore, in adult humans fed a 4-wk arginine-free diet, the decrease in oxidation was similar to a 1-wk restriction alone $(15,18)$.

Previous studies demonstrated that the carryover effect of the isotope did not affect the background enrichment after $2 \mathrm{~d}$ (19). Most studies used a latency of $2 \mathrm{~d}(20,21)$ or $7 \mathrm{~d}$ $(22,23)$ between two measurements. We determined a tracer washout time of $7.5 \mathrm{~h}$. This makes it possible to measure the 
a

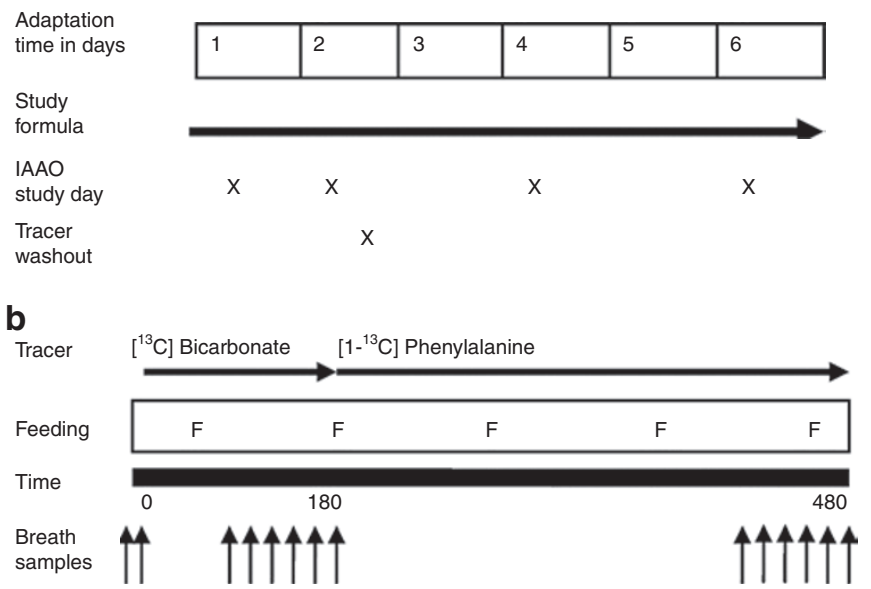

Figure 4. Study design. $X=$ indicator amino acid oxidation (IAAO) study day. (a) Overview of the study design: adaptation days and study days. (b) Study design at one IAAO study day.

same patient on two consecutive study days, as we did in the current study.

A significant increase was observed in the baseline ${ }^{13} \mathrm{C}$ enrichment at day 1 as compared with days 2, 4, and 6, implying that time is needed to adapt to the ${ }^{13} \mathrm{C}$ enrichment of the study diet. Because every diet differs in naturally enriched ${ }^{13} \mathrm{C}$ depending on the carbohydrate source used (24), a period of time is necessary to allow background adaptation to the experimental diet. This is probably a result of the fact that we used European formulas, which might be based on different sources of carbohydrates and proteins than the Chinese formula that the infants received before the adaptation day. A limitation of the present study is that because of the large increase of $6-7 \delta \mathrm{PDB}$ in baseline enrichments after the start of the study formula on day 1 , the $\mathrm{F}^{13} \mathrm{CO}_{2}$ on day 1 was not comparable with that measured on the other days. The differences between days 2,4 , and 6 were considered not relevant because they are within $1 \delta$ PDB difference, which is within the precision range of this technique.

In conclusion, our study indicates that a period of time is necessary to adapt to the ${ }^{13} \mathrm{C}$ level of the study formula, and this adaptation occurs within $24 \mathrm{~h}$. Furthermore, if adaptation to a specific deficient diet has occurred, a tracer study as described here can be performed as often as every day. No conclusive evidence has been generated as to how long an adaptation period on a deficient diet should last. No differences were observed between 2 and $4 \mathrm{~d}$ adaptation to the study diet, whereas at day 6 , significant changes in metabolism were observed, most likely as a result of a protein-sparing adaptive response.

\section{METHODS}

\section{Subjects}

Subjects eligible for the study were preterm infants admitted to the Neonatology Department of the Fudan Children's Hospital in Shanghai, China. Their gestational ages ranged between 28 and $37 \mathrm{wk}$, and their birth weights were $<2.2 \mathrm{~kg}$. The children had to be clinically stable and in a growth state, defined as gaining weight at a rate $>10 \mathrm{~g} /$ $\mathrm{kg} / \mathrm{d}^{-1}$ over the previous $5 \mathrm{~d}$. All subjects tolerated full enteral feeding well and had no congenital or gastrointestinal diseases. The study
Table 3. Intakes of essential amino acids compared with current recommendations

\begin{tabular}{lcc}
\hline & $\begin{array}{c}\text { Minimum amino acid } \\
\text { recommendations } \\
\text { for preterm infants } \\
(\mathrm{mg} / 135 \mathrm{kcal})(14)\end{array}$ & $\begin{array}{c}\text { Study formula } \\
\text { containing leucine } \\
166 \mathrm{mg} / \mathrm{kg} / \mathrm{d} \\
(\mathrm{mg} / 135 \mathrm{kcal})\end{array}$ \\
\hline Leucine & 340 & 166 \\
Histidine & 72 & 191 \\
Isoleucine & 174 & 174 \\
Lysine & 246 & 307 \\
Phenylalanine and tyrosine & 265 & Phe: $224 ; \mathrm{Tyr}: 220$ \\
Sulfur amino acid & 115 & Met: $83 ;$ Cys:121 \\
(methionine and cysteine) & 153 & 214 \\
Threonine & 51 & 82 \\
Tryptophan & 178 & 194 \\
Valine & &
\end{tabular}

Cys, cysteine; Met, methionine; Phe, phenylalanine; Tyr, tyrosine.

protocol was approved by the medical ethical committee of the Fudan Children's Hospital, and a statement of no objection was obtained from the medical ethical committee of the Erasmus MC-Sophia's Children's Hospital. Similar studies, including those determining cysteine requirements, have been performed previously in the Erasmus MC Sophia Children's Hospital $(25,26)$. Written informed consent was obtained from one or both parents for all participants after a Mandarin-speaking researcher provided a precise explanation of the study.

\section{Experimental Design}

Tracer washout time. The tracer washout time was determined once in all 11 subjects on day 2 . Breath samples were collected directly after the enteral infusion of $\left[1-{ }^{13} \mathrm{C}\right]$ phenylalanine was stopped (T0) and subsequently every hour during the first $9 \mathrm{~h}$. Over the following $6 \mathrm{~h}$, breath samples were collected every $2 \mathrm{~h}$. Subsequently, samples were collected every $3 \mathrm{~h}$ for $9 \mathrm{~h}$ until a 24 -h period had passed since the beginning of the tracer washout study. These samples were compared with the baseline samples of the study day to determine the time needed between two tracer study days. Subjects were weighed daily, and a head circumference was measured on the days on which indirect amino acid oxidation study was performed. The study protocol is shown in Figure 4.

Adaptation study. Tracer studies were performed on days 1, 2, 4, and 6. On the study days, baseline samples were obtained 15 and $5 \mathrm{~min}$ before starting the tracer infusion. Directly after the first study formula was administered, subjects received a primed $(10 \mu \mathrm{mol} / \mathrm{kg})$ continuous $(10 \mu \mathrm{mol} / \mathrm{kg} / \mathrm{h})$ enteral infusion of $\left[{ }^{13} \mathrm{C}\right]$ bicarbonate (sterile pyrogen free, $99 \%{ }^{13} \mathrm{C}$ APE; Cambridge Isotopes, Woburn, MA) for $2.5 \mathrm{~h}$ to quantify individual $\mathrm{CO}_{2}$ production. The labeled sodium bicarbonate infusion was directly followed by a primed $(30 \mu \mathrm{mol} / \mathrm{kg})$ continuous $(30 \mu \mathrm{mol} / \mathrm{kg} / \mathrm{h})$ enteral infusion of $\left[1-{ }^{13} \mathrm{C}\right]$ phenylalanine (99\% ${ }^{13} \mathrm{C}$ APE; Cambridge Isotopes) for $5 \mathrm{~h}$ by an infusion pump via the nasogastric tube. Breath samples were collected on all study days and were obtained using the direct sampling method described by Van der Schoor et al. (27). During the experiment duplicate, ${ }^{13} \mathrm{C}$-enriched breath samples were collected every 15 min during the isotopic steady state, beginning $1.75 \mathrm{~h}$ after start of $\left[{ }^{13} \mathrm{C}\right]$ bicarbonate administration and $3 \mathrm{~h}$ after the start of $\left[1-{ }^{13} \mathrm{C}\right]$ phenylalanine administration, as depicted in Figure 4.

\section{Study Formula}

The study formula contained $166 \mathrm{mg} / \mathrm{kg} / \mathrm{d}$ leucine, which is $50 \%$ below the current recommended intake for preterm neonates (28). Subjects received the leucine-low study formula for $6 \mathrm{~d}$. Except leucine, all the other essential amino acids were present at levels above the current recommendations and are presented in Table 3. 
These amino acid concentrations were obtained by mixing a leucine-free formula, which also contained decreased amounts of valine and isoleucine (Analog, Danone/SHS International, Liverpool, UK) with regular Neocate, an amino acid based formula designed to fulfill the amino acid requirements of infants (Danone/SHS International). Before the start of the study formula, subjects received Chinese formula from different brands. All subjects received the study formula in 8-12 boluses for $6 \mathrm{~d}$. On these days, subjects received a fluid intake of $170 \mathrm{ml} /$ $\mathrm{kg} / \mathrm{d}$, which provided $135 \mathrm{kcal} / \mathrm{kg} / \mathrm{d}$ and a protein intake of $3.7 \mathrm{~g} / \mathrm{kg} / \mathrm{d}$, according to the current recommendations for preterm infants (28).

\section{Analysis and Calculations}

Samples were sent from Shanghai to Rotterdam every 3 wk by air transport. The ${ }^{13} \mathrm{CO}_{2}$ isotopic enrichment in expired air was measured using infrared spectrometric analysis (Helifan, Analytic Fischer Instruments, Leipzig, Germany) and expressed as APE above baseline. The isotopic ratio of a sample is calculated relative to the international standard PDB. The results of this differential measurement are expressed as $\delta \%$ difference between the ${ }^{13} \mathrm{CO}_{2} /{ }^{12} \mathrm{CO}_{2}$ ratio and the standard. From the $\delta^{13} \mathrm{C}$ value, the atom percent $(\mathrm{AP}){ }^{2} \mathrm{C}$ can be calculated as described by Schierbeek et al. (29). To calculate the APE, the $\mathrm{AP}_{\text {(background) }}$ is subtracted from the $\mathrm{AP}$ (sample) . APE was plotted relative to time.

Estimated body $\mathrm{CO}_{2}$ production $(\mathrm{mmol} / \mathrm{kg} / \mathrm{h})$ was calculated for each infant as described previously (25). The $\mathrm{F}^{13} \mathrm{CO}_{2}$ was calculated using the following equation:

$$
\mathrm{F}^{13} \mathrm{CO}_{2}(\%)=\left(\mathrm{IE}_{\mathrm{PHE}} \times \mathrm{i}_{\mathrm{B}}\right) /\left(\mathrm{i}_{\mathrm{PHE}} \times \mathrm{IE}_{\mathrm{B}}\right) \times 100(30)
$$

where $\mathrm{IE}_{\mathrm{PHE}}$ is the ${ }^{13} \mathrm{C}$ isotopic enrichment in expired air during $\left[1-{ }^{13} \mathrm{C}\right]$ phenylalanine infusion $(\mathrm{APE}), \mathrm{i}_{\mathrm{B}}$ is the infusion rate of $\left[{ }^{13} \mathrm{C}\right]$ bicarbonate $(\mu \mathrm{mol} / \mathrm{kg} / \mathrm{h}), \mathrm{i}_{\mathrm{PHE}}$ is the infusion rate of $\left[1-{ }^{13} \mathrm{C}\right]$ phenylalanine $(\mu \mathrm{mol} / \mathrm{kg} / \mathrm{h})$, and $\mathrm{IE}_{\mathrm{B}}$ is the ${ }^{13} \mathrm{C}$ isotopic enrichment in expired air during $\left[{ }^{13} \mathrm{C}\right]$ bicarbonate infusion.

\section{Statistical Analysis}

Steady state of ${ }^{13} \mathrm{CO}_{2}$ in expired breath during the $\left[1-{ }^{13} \mathrm{C}\right]$ phenylalanine was achieved when the linear factor of the slope was found to be not significantly different from zero $(P \geq 0.05)$. Biphasic linear regression analysis was performed to analyze oxidation rates as described below. Statistical analyses were performed using SPSS (SPSS, Chicago, IL). A $P$ value $\leq 0.05$ was considered significant. For the washout time, a biphasic regression analysis was determined on the breath enrichment values. In this model, a break point is estimated using nonlinear regression. With the biphasic linear regression analysis, the regression equation was split into two parts. For the first part, an intercept and slope were estimated. For the second part, the slope was restricted to zero. Therefore, the estimated intercept of the second line was equal to the break point. The model with the best fit on the basis of the highest $r^{2}$ was selected. A paired $t$-test was used to determine the differences before and during the study day and to compare measurements from day 1 to those from days 2,4 , and 6 . The effects of growth during the study and the $\mathrm{F}^{13} \mathrm{CO}_{2}$ were tested with Pearson's correlation coefficient analysis.

\section{ACKNOWLEDGMENTS}

We thank the infants and their parents who participated in this study. We also thank the nurses and doctors of the neonatal ward in the Children's Hospital of the Fudan University for their support and help.

\section{STATEMENT OF FINANCIAL SUPPORT}

The study formula was manufactured by Scientific Hospital Supplies (SHS) International, UK, and transportation to Shanghai was facilitated by Dumex China. Financial support was provided by Danone. The study sponsors had no influence on the study design, the analysis of the data, or the writing of the article.

\section{Disclosure: The authors declare no conflict of interest.}

\section{REFERENCES}

1. Rand WM, Young VR, Scrimshaw NS. Change of urinary nitrogen excretion in response to low-protein diets in adults. Am J Clin Nutr 1976;29:639-44.
2. Harper AE. Diet and plasma amino acids. Am J Clin Nutr 1968;21:358-66.

3. Young VR, Pelletier VA. Adaptation to high protein intakes, with particular reference to formula feeding and the healthy, term infant. J Nutr 1989;119:Suppl 12:1799-809.

4. Bross R, Ball RO, Pencharz PB. Development of a minimally invasive protocol for the determination of phenylalanine and lysine kinetics in humans during the fed state. J Nutr 1998;128:1913-9.

5. Elango R, Humayun MA, Ball RO, Pencharz PB. Indicator amino acid oxidation is not affected by period of adaptation to a wide range of lysine intake in healthy young men. J Nutr 2009;139:1082-7.

6. Krempf M, Hoerr RA, Pelletier VA, Marks LM, Gleason R, Young VR. An isotopic study of the effect of dietary carbohydrate on the metabolic fate of dietary leucine and phenylalanine. Am J Clin Nutr 1993;57:161-9.

7. Van Goudoever JB, Colen T, Wattimena JL, Huijmans JG, Carnielli VP, Sauer PJ. Immediate commencement of amino acid supplementation in preterm infants: effect on serum amino acid concentrations and protein kinetics on the first day of life. J Pediatr 1995;127:458-65.

8. Lucas A, Morley R, Cole TJ. Randomised trial of early diet in preterm babies and later intelligence quotient. BMJ 1998;317:1481-7.

9. Stephens BE, Walden RV, Gargus RA, et al. First-week protein and energy intakes are associated with 18-month developmental outcomes in extremely low birth weight infants. Pediatrics 2009;123:1337-43.

10. Singhal A, Cole TJ, Lucas A. Early nutrition in preterm infants and later blood pressure: two cohorts after randomised trials. Lancet 2001;357:413-9.

11. Moehn S, Bertolo RF, Pencharz PB, Ball RO. Indicator amino acid oxidation responds rapidly to changes in lysine or protein intake in growing and adult pigs. J Nutr 2004;134:836-41.

12. Christensen HN. Interorgan amino acid nutrition. Physiol Rev 1982;62(4 Pt 1):1193-233.

13. Young VR, Meredith C, Hoerr R, Bier DM, Matthews DE. Amino acid kinetics in relation to protein and amino acid requirements: the primary importance of amino acid oxidation. In: Substrate and Energy Metabolism in Man. London: John Libbey 1985:119-34.

14. Hiramatsu T, Cortiella J, Marchini JS, Chapman TE, Young VR. Plasma proline and leucine kinetics: response to $4 \mathrm{wk}$ with proline-free diets in young adults. Am J Clin Nutr 1994;60:207-15.

15. Tharakan JF, Yu YM, Zurakowski D, Roth RM, Young VR, Castillo L. Adaptation to a long term (4 weeks) arginine- and precursor (glutamate, proline and aspartate)-free diet. Clin Nutr 2008;27:513-22.

16. Young VR, Gucalp C, Rand WM, Matthews DE, Bier DM. Leucine kinetics during three weeks at submaintenance-to-maintenance intakes of leucine in men: adaptation and accommodation. Hum Nutr Clin Nutr 1987;41:1-18.

17. Duncan AM, Ball RO, Pencharz PB. Lysine requirement of adult males is not affected by decreasing dietary protein. Am J Clin Nutr 1996;64:718-25.

18. Castillo L, Sánchez M, Chapman TE, Ajami A, Burke JF, Young VR. The plasma flux and oxidation rate of ornithine adaptively decline with restricted arginine intake. Proc Natl Acad Sci USA 1994;91:6393-7.

19. Zello GA, Pencharz PB, Ball RO. Phenylalanine flux, oxidation, and conversion to tyrosine in humans studied with L-[1-13C]phenylalanine. Am J Physiol 1990;259(6 Pt 1):E835-43.

20. Kriengsinyos W, Wykes LJ, Ball RO, Pencharz PB. Oral and intravenous tracer protocols of the indicator amino acid oxidation method provide the same estimate of the lysine requirement in healthy men. J Nutr 2002;132:2251-7.

21. Darling PB, Dunn M, Sarwar G, Brookes S, Ball RO, Pencharz PB. Threonine kinetics in preterm infants fed their mothers' milk or formula with various ratios of whey to casein. Am J Clin Nutr 1999;69:105-14.

22. Riazi R, Rafii M, Clarke JT, Wykes LJ, Ball RO, Pencharz PB. Total branchedchain amino acids requirement in patients with maple syrup urine disease by use of indicator amino acid oxidation with L-[1-13C]phenylalanine. Am J Physiol Endocrinol Metab 2004;287:E142-9.

23. Turner JM, Humayun MA, Elango R, et al. Total sulfur amino acid requirement of healthy school-age children as determined by indicator amino acid oxidation technique. Am J Clin Nutr 2006;83:619-23. 


\section{Articles | de Groofet al.}

24. Schoeller DA, Klein PD, Watkins JB, Heim T, MacLean WC Jr. 13C abundances of nutrients and the effect of variations in $13 \mathrm{C}$ isotopic abundances of test meals formulated for $13 \mathrm{CO} 2$ breath tests. Am J Clin Nutr 1980;33:2375-85.

25. Riedijk MA, Voortman G, van Goudoever JB. Use of [13C]bicarbonate for metabolic studies in preterm infants: intragastric versus intravenous administration. Pediatr Res 2005;58:861-4.

26. Riedijk MA, Voortman G, van Beek RH, Baartmans MG, Wafelman LS, van Goudoever JB. Cyst(e)ine requirements in enterally fed very low birth weight preterm infants. Pediatrics 2008;121:e561-7.
27. van der Schoor SR, de Koning BA, Wattimena DL, Tibboel D, van Goudoever JB. Validation of the direct nasopharyngeal sampling method for collection of expired air in preterm neonates. Pediatr Res 2004;55:50-4.

28. Klein CJ. Nutrient requirements for preterm infant formulas. J Nutr 2002;132:6 Suppl 1:1395S-577S.

29. Schierbeek H, van den Akker CH, Fay LB, van Goudoever JB. High-precision mass spectrometric analysis using stable isotopes in studies of children. Mass Spectrom Rev 2012;31:312-30.

30. van der Schoor SR, Reeds PJ, Stellaard F, et al. Lysine kinetics in preterm infants: the importance of enteral feeding. Gut 2004;53:38-43. 